\title{
Presence and patterns of alkaline phosphatase activity and phosphorus cycling in natural riparian zones under changing nutrient conditions
}

\author{
Peifang WANG, ${ }^{*}$ Lingxiao REN, Chao WANG, Jin QIAN, Jun HOU \\ Key Laboratory of Integrated Regulation and Resource Department on Shallow Lakes, Ministry of Education, College of Environment, \\ Hohai University, 1 Xikang Road, Nanjing 210098, China \\ *Corresponding author: pfwang2005@hhu.edu.cn
}

\begin{abstract}
Phosphorus $(P)$ is an important limiting nutrient in aquatic ecosystems and knowledge of $P$ cycling is fundamental for reducing harmful algae blooms and other negative effects in water. Despite their importance, the characteristics of P cycling under changing nutrient conditions in shallow lakes were poorly investigated. In this study, in situ incubation experiments were conducted in a natural riparian zone in the main diversion channel used for water transfer into Lake Taihu (Wangyu River). Variations in microbial biomass, dissolved P fractions (organic and inorganic), and alkaline phosphatase activity (bulk APA and specific APA) were determined after incubation with and without the addition of $P$ and nitrogen $(N)$ (4 total water treatments: $+P,+N,+N P$, and control). Experiments were conducted during two seasons (late spring and early fall) to account for natural differences in nutrient levels that may occur in situ. Our results demonstrated that low levels of DRP may not necessarily indicate P limitation. Phytoplankton exhibited serial N limitation with P stress in May, such that chlorophyll a (Chl a) increased significantly with $N$ addition, while the limiting nutrient shifted to P in October and phytoplankton biomass increased with $P$ addition. Phytoplankton contributed greatly to APA production and was significantly influenced by P bioavailability, yet high levels of bulk APA were also not necessarily indicative of P limitation. In contrast to phytoplankton, bacteria were less $P$ stressed. As a consequence of enhanced utilization of dissolved reactive $P(D R P)$ and dissolved organic $P(D O P),+N$ treatment elevated APA significantly. By contrast, APA could be repressed to low values and phytoplankton converted a large portion of DRP to DOP with P addition. But this was not consistent with bacteria APA (bact-APA) in the absence or presence of abundant phytoplankton biomass. The correlation between bulk APA and DRP was good at separate sites and discrepant for the whole data set. Regulation of APA was demonstrated by an inverse hyperbolic relationship between bulk APA, specific APA, and DRP, with a transition from high to low activity occurring between 20 and $50 \mu g L^{-1}$. This study provides a better understanding of how APA and P cycling change with nutrient perturbations in Lake Taihu system. The obtained results can help understanding the process of $P$ cycling in water and providing a reference for nutrient control in the water transfer project.
\end{abstract}

Key words: Phosphorus, phytoplankton, bacteria, dissolved reactive phosphorus, dissolved organic phosphorus, alkaline phosphatase activity (APA).

Received: April 2014. Accepted: August 2014.

\section{INTRODUCTION}

Increasing nutrient inputs have caused eutrophication in aquatic ecosystems worldwide over the last several decades (Smith et al., 1999; Carpenter, 2005). Phosphorus (P), an essential nutritive element for organisms (Hecky and Kilham, 1988; Sañudo-Wilhemy et al., 2001), has long been recognized as the primary limiting nutrient in fresh waters (Wetzel, 2001; Paerl, 2008). For example, Yang (2004) suggested that $\mathrm{P}$, and not nitrogen $(\mathrm{N})$, was the nutrient limiting Microcystis spp. growth in Lake Taihu. Schindler et al. (2008) suggested that only P reductions were needed to protect aquatic ecosystems and $\mathrm{N}$ reductions might be not necessary, although other studies indicate the causes may be more complicated (Galloway and Gowling, 2002; Rabalais, 2002). As such, the understanding of $\mathrm{P}$ cycling is critical for reducing or preventing eutrophication and associated harmful algal blooms in freshwater systems (Correll, 1998; Anderson et al., 2002). Currently, the role of $\mathrm{P}$ limitation in freshwater microorganisms and how $\mathrm{P}$ assimilation is regulated is an important matter of debate in freshwater limnology.

With the exception of phagotrophic protists, microbial cells are able to take up only inorganic phosphates from the surrounding environment (Reynolds, 1997). Despite decades of research focusing on dissolved reactive P (DRP, mainly as inorganic phosphates), growing evidence indicates that dissolved organic $\mathrm{P}$ (DOP) is an important driver of limnological production (Labry et al., 2002; Boyer et al., 2006). As a most-studied enzyme, capable of hydrolyzing a broad spectrum of DOP, alkaline phosphatase (APase) and its activity (APA) have also received increasing attention and are considered to be indicative of $\mathrm{P}$ status in both algal cultures and natural phytoplankton populations (Cembella et al., 1984; Dyhrman et al., 2002; Novotna, 2010). For example, Gao et al. (2006) found that APase can hydrolyze $\sim 58 \%$ of total $\mathrm{P}$ in a shallow lake in China (Lake Taihu) and thereby compensate for the growth of algae. In 
a study in Gamak Bay (Korea), Kwon et al. (2011) found that APA and phosphatase hydrolyzed P supplemented DRP and thus contributed to the dominance of bloom species. However, bacteria are also important competitors for $\mathrm{P}$ and producers of APA. Yet, studies of APA have mainly focused on total APA in unfiltered samples, and surveys examining the different origins of APA are relatively scarce.

Despite increasing research on DRP assimilation and APA regulation, most studies have not provided an in situ measure or prediction of these processes because the patterns vary with environmental conditions. Phytoplankton growth and APA can be influenced by altered nutrient regimes over short time intervals (Xu et al., 2010; Duhamel et al., 2010). In this regard, short-term nutrient manipulation bioassays may provide a useful tool to address how $\mathrm{P}$ cycling responses to enhanced nutrient concentrations. For example, Rose and Axler (1997) demonstrated the utility of APA as a reliable indicator of P deficiency of phytoplankton in nutrient addition experiments. Ruttenberg and Dyhrman (2012) evaluated DOP production patterns during simulated phytoplankton blooms, to investigate the dynamics of DOP pool in the costal system. Though these studies have contributed significantly to our understanding of DRP assimilation and APA regulation, they have mostly focused on marine systems and the nature of these processes in shallow lake systems is relatively unknown.

In this paper, in situ incubation experiments were conducted in a natural riparian zone in Wangyu River in Jiangsu, China. This river has played an important role in the water transfer project from the Yangtze River to Lake Taihu. We conducted the experiment in late spring and early autumn, when phytoplankton blooms and resultant depletion of $\mathrm{P}$ usually occur. By nutrients enrichment, we examined variations in microbial biomass, dissolved $\mathrm{P}$ fractions (organic and inorganic), and APA (bulk APA and specific APA) in each season. The goals were to: i) determine the nutrient limitation of phytoplankton during each season; ii) examine how APA fractions respond to nutrient addition; iii) quantify changes in $\mathrm{P}$ fractions with perturbation of nutrient conditions. The results of this study could be used to provide a better understanding of how APA production and $P$ cycling change with nutrient perturbations in Lake Taihu system and to estimate the scenarios that most closely occur in situ, and will provide a reference for nutrient control in the water transfer project.

\section{METHODS}

\section{Study area and field sampling}

Wangyu River, which is $60.8 \mathrm{~km}$ long, originates from the Yangtze River and joins Lake Taihu, flowing all the way through several natural riparian zones. It is the main diversion channel used in the water transfer project from the Yangtze River to Lake Taihu and serves as an impor- tant barrier to pollutants entering the lake (Jin and $\mathrm{Hu}$, 2003; Hu et al., 2008) (Fig. 1). As a typical characteristic of Taihu Basin, these riparian zones (e.g., Ezhen area) are located along Wangyu and their entrances and exits are positioned in the river. There are small plots of natural wetland and a great deal of aquatic plants inside. The naturally-growing hydrophyte help protect water quality and their generation alternations also occur naturally. These riparian zones have existed for many years and they played important roles in water purification and environmental protection in the river (Ren et al., 2013). They were characterized by small water areas, meandering shorelines and poor liquidity years ago. When the water transfer project began, they were restored, dredged and expanded with the modified diversion channel.

Our study sites were situated in the Ezhen area, the first natural riparian zone from the origin of Wangyu River. It covers $3.0 \mathrm{~km}$ north-south by $2.9 \mathrm{~km}$ east-west, with a surface area of $5.4 \mathrm{~km}^{2}$ and an average depth of $\sim 2.0 \mathrm{~m}$. Because of shallow depth and persistent local winds, stratification is usually absent or obscure and water level fluctuations are not very accentuated. In the light of its water depth, surface patterns and flow structures, Ezhen area can be considered as a river-type shallow lake. With Wangyu River flowing through it, water velocity fluctuates and becomes steady along the mainstream line. Yet in other areas, particular close to the banks or near the small plots of natural wetland, it decreases to low values and Ezhen area functions more like a shallow lake. There are villages close by and there has been agricultural activity for many years. It has been used mainly for shipping and fish farming, as well as water supply and irrigation.

Riverine discharge is indicated as the main nutrient source in Taihu watershed (Xu et al., 2010; Lai et al., 2006). Large amounts of untreated wastewater from factories and residential areas are discharged into Wangyu River through its polluted western side rivers (Hu et al., 2008, 2010), bringing substantial exogenous nutrients into Ezhen, which could significantly impact the water quality into Lake Taihu and the efficiency of the water transfer project. Hence, it is desirable for us to study the patterns of P cycling and phytoplankton nutrient limitation, and to investigate if APA patterns were consistent with expected responses under changing nutrient conditions. Three sites were selected in this study: site $1\left(31^{\circ} 31.5^{\prime} \mathrm{N}, 120^{\circ} 34.5^{\prime} \mathrm{E}\right)$ was near the entrance of the Ezhen, site $2\left(31^{\circ} 31.0^{\prime} \mathrm{N}, 120^{\circ} 34.1^{\prime} \mathrm{E}\right)$ was in the center and site $3\left(31^{\circ} 30.5^{\prime} \mathrm{N}, 120^{\circ} 34.6^{\prime} \mathrm{E}\right)$ was in the hydrophyte region.

Water samples containing natural phytoplankton assemblages were collected in May (late spring) and October (early autumn) 2011, seasons that were characterized by the recovery and the bloom of phytoplankton. At each site, discrete samples were collected at three depths $(0.5 \mathrm{~m}$, $1 \mathrm{~m}$, and $0.5 \mathrm{~m}$ from bottom) with a Friedinger water sam- 
pler, and diverted into 25-L carboys. Before incubation experiments, water was prescreened through $200-\mu \mathrm{m}$ Nitex $^{\circledR}$ mesh to remove large zooplankton. To prevent contamination, all sample containers were rinsed with $10 \%$ hydrochloric acid $(\mathrm{HCl})$, followed by deionized water and sampled water prior to collection. Results of determination of the initial biogeochemical parameters are in Tab. 1.

\section{Incubation experiments}

To determine whether $\mathrm{N}$ or $\mathrm{P}$ limited phytoplankton and bacteria growth, water samples from each site were distributed into nine 1-L polyethylene cubitainers
(Changzhou Sanjie Co., Jiangsu, China) that were chemically inert, unbreakable and transmit $\sim 85 \%$ of photosynthetically active radiation (PAR: $400-700 \mathrm{~nm}$ ). The methodology and deployment procedures of cubitainer bioassays are detailed in Paerl and Bowles (1987) and Paerl et al. (2011). PAR within each cubitainer was estimated with Li-cor 192SA spherical sensor. With triplicate for each treatment, they were marked as $+\mathrm{N},+\mathrm{P},+\mathrm{NP}$ and control (no nutrient additions) treatment, respectively. $\mathrm{N}$ was added as equimolar fractions of $\mathrm{KNO}_{3}$ and $\mathrm{NH}_{4} \mathrm{Cl}$, and $\mathrm{P}$ was added as $\mathrm{K}_{2} \mathrm{HPO}_{4} \cdot 3 \mathrm{H}_{2} \mathrm{O}$. The final concentration of dissolved inorganic nitrogen (DIN, defined as the

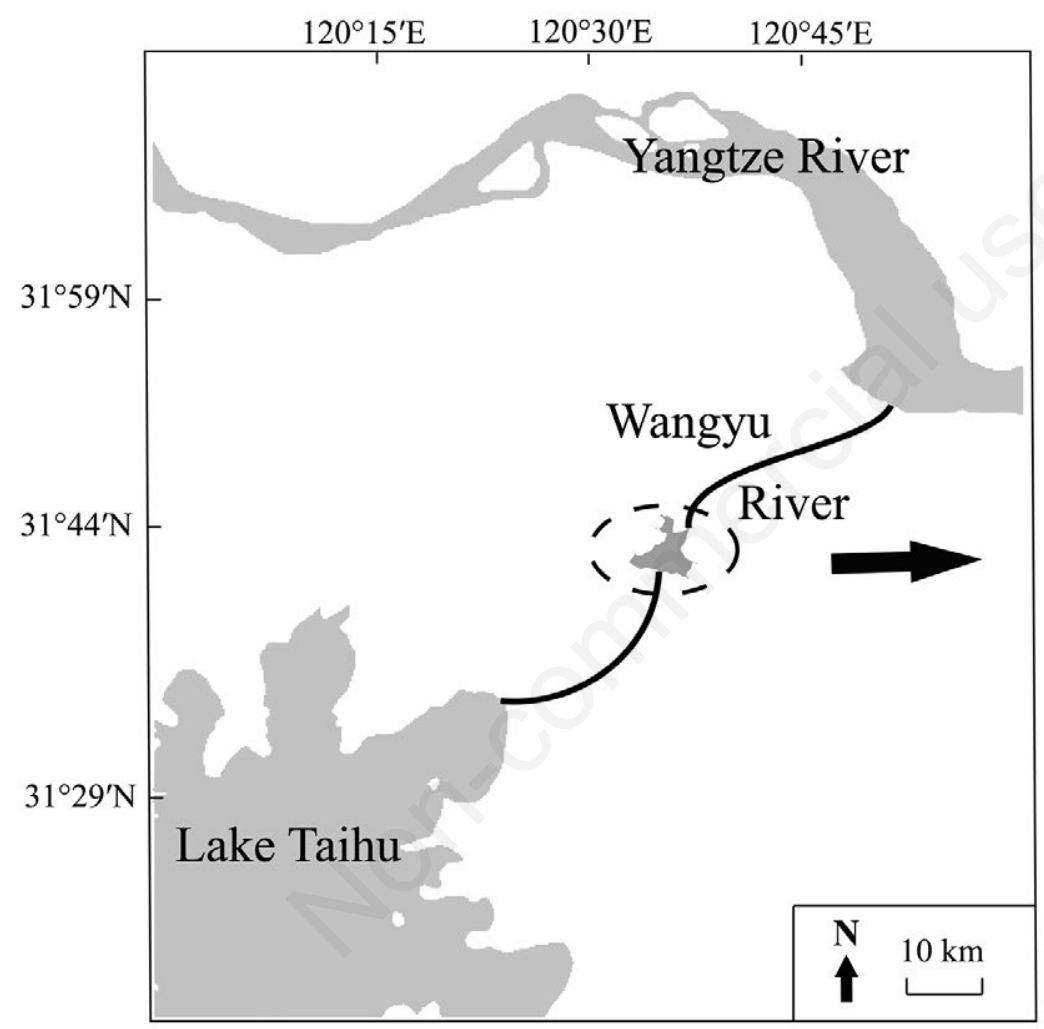

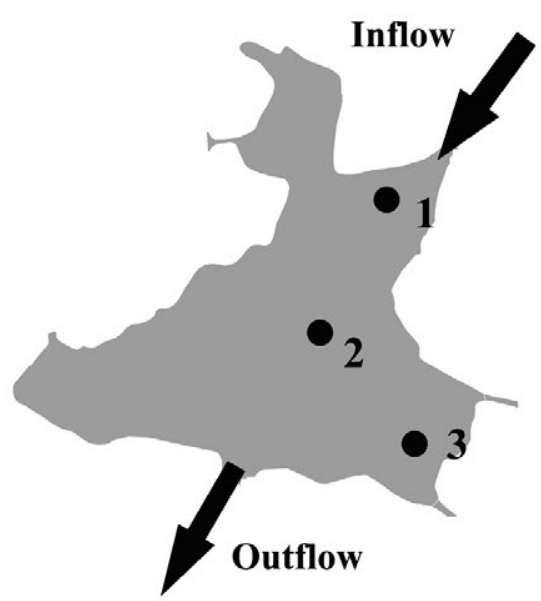

Ezhen Riparian Area

Fig. 1. Research area and sampling sites.

Tab. 1. Initial conditions of the sampling sites.

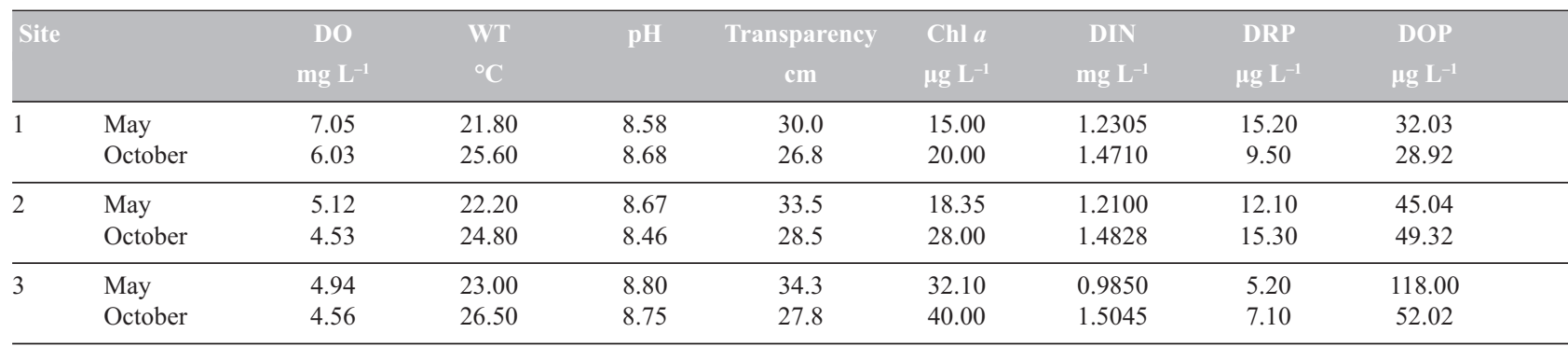

DO, dissolved oxygen; $W T$, water temperature; DIN, dissolved inorganic nitrogen; DRP, dissolved reactive phosphorus; DOP, dissolved organic phosphorus. 
sum of ammonium, nitrite and nitrate) was $2.00 \mathrm{mg} \mathrm{L}^{-1}$, and the final concentration of DRP was $0.15 \mathrm{mg} \mathrm{L}^{-1}$. After thorough mixing, the cubitainers were deployed near the surface at each site with a floating steel frame, which allowed for natural light, in situ water temperature and turbulence conditions. Headspace in cubitainers ensured daily gas exchange and mixing. At the start of the incubation experiments (day 1), additional water samples were collected for analyses of chlorophyll $a(\mathrm{Chl} a)$ and nutrients (N, P). During incubation, $\sim 300 \mathrm{~mL}$ subsamples were taken from each cubitainer periodically for laboratory analyses. The cubitainers were sealed during incubations, and subsampling was completed in less than $10 \mathrm{~min}$.

\section{Analytical methods}

\section{Nutrient analysis}

Analysis of dissolved $\mathrm{P}$ fractions was performed on days 1, 3 and 5 . Water samples were brought to the field laboratory station and filtered immediately after collection (usually within $10 \mathrm{~min}$ ). Five $\mathrm{mL} \mathrm{HgCl}_{2}$ (final concentration of $100 \mathrm{mg} \mathrm{L}^{-1}$ ) was added to each sample to prevent microbial enzymatic activity (Kwon et al., 2011). Water samples were filtered through $\mathrm{GF} / \mathrm{F}$ filters $(0.45 \mu \mathrm{m}$ pore size, Millipore Co., Billerica, MA, USA) under low vacuum pressure $(<15 \mathrm{~cm} \mathrm{Hg})$ to minimize cell lysis. Filtrates were collected in acid-washed polypropylene bottles, acidified to $\mathrm{pH} 1$, and refrigerated until analysis. DIN was measured according to the APHA (1995). DRP was estimated using the colorimetric method (Murphy and Riley, 1962) and total dissolved P (TDP) was measured after acid hydrolysis with persulfate digestion for 60 min under high temperature and pressure. DOP was calculated by subtracting DRP from TDP.

\section{APA analysis}

Water samples were processed for detection of APA within $2 \mathrm{~h}$ from collection. APA was determined as the release rate of $p$-nitrophenol $(p \mathrm{NP})$ using the artificial fluorogenic substrate $p$-nitrophenylphosphate ( $p$ NPP) (Chróst and Overbeck, 1987). The reaction mixture contained $4.5 \mathrm{~mL}$ of water sample, $p$ NPP (final concentration of $0.2 \mathrm{mmol} \mathrm{L}^{-1}$ ), $\mathrm{Na}_{3} \mathrm{~N}$ (final concentration of $5 \mathrm{mmol} \mathrm{L}{ }^{-1}$ ), and Tris/ $\mathrm{HCl}$ buffer solution $(\mathrm{pH}=8.0)$. After incubation at in situ water temperature for $30 \mathrm{~min}$, the enzymatic hydrolysis was stopped with $1 \mathrm{~mL}$ of $2 \mathrm{~mol} \mathrm{~L}^{-1} \mathrm{NaOH}$ solution. With intensive stirring, $p \mathrm{NP}$ was determined by spectrophotometry at $410 \mathrm{~nm}$ in 1-cm cuvettes and corrected with a blank.

Phytoplankton and bacteria are important competitors for available nutrients in aquatic ecosystems. Because both phytoplankton and bacteria synthesize APA, selective filtration can discriminate between algal and bacterial APA, although there may be some error because overlap (Labry et al., 2005; Ivančić et al., 2010). Bulk APA was determined in unfiltered samples $\left(\mathrm{APA}_{\mathrm{T}}\right)$ every day and specific APA was determined in samples filtered through $3 \mu \mathrm{m}$ and $0.22 \mu \mathrm{m}$ membrane filters $\left(\mathrm{APA}_{<3}\right.$ and $\left.\mathrm{APA}_{<0.22}\right)$ on days 1,3 and 5 . The coarse fraction $\left(\mathrm{APA}_{>3}\right)$ derives mainly from algae and was defined as phyt-APA and calculated as:

$$
\mathrm{APA}_{>3}=\mathrm{APA}_{\mathrm{T}}-\mathrm{APA}_{<3}
$$

The finer fraction $\left(\mathrm{APA}_{0.22-3}\right)$, mainly derives from bacteria and picoplankton, was defined as bact-APA and calculated as:

$$
\mathrm{APA}_{0.22-3=3} \mathrm{APA}_{<3}-\mathrm{APA}_{<0.22}
$$

The dissolved $\left(\mathrm{APA}_{<0.22}\right)$ fraction was termed free APA (Liu et al., 2012).

\section{Physical parameters}

Physical parameters, including surface water temperature (WT), dissolved oxygen (DO) and $\mathrm{pH}$ were measured in the field using a multisensory sonde by (Yellow Springs Instruments (YSI Inc., Yellow Springs, OH, USA). Chl $a$ was determined each day using ethanol extraction (Golterman et al., 1978). Water samples (0.1 L) were filtered through GF/F filters $(0.45 \mu \mathrm{m}$ pore size, Millipore) and, after overnight extraction in ethanol $(90 \%$ $\mathrm{v} / \mathrm{v}$ ), the absorbance was measured at 665 and $750 \mathrm{~nm}$ in 1 -cm path-length glass cuvettes. Bacteria were counted directly after staining formalin-fixed bacterial cells ( $2 \%$ final concentration) with DAPI (Porter and Feig, 1980) using an epifluorescence microscope.

\section{Statistical analyses}

To ensure the precision of the experiment results, all the samples were analysed in triplicate, and results were reported as the average values. Data were analysed using SPSS 17.0 statistical software for analysis. Where reported, statistical significance $(\mathrm{P}<0.05)$ was determined with pair wise comparisons using $t$-tests.

\section{RESULTS}

\section{Phytoplankton and bacterial biomass}

Chl $a$ and bacterial numbers can effectively represent algal and bacterial biomass. In recent years, nutrient enrichment bioassays have been used to identify potential nutrient limitation for microbial communities in fresh and marine waters (Rengefors et al., 2003). Because growth response is expected to be proportional to the increase in nutrient levels whenever the nutrient is limiting (Geraldes and Boavida, 2003), nutrient bioassays allow a direct assessment of limitation, whereas traditional methods use stoichiometric ratios to infer limitation.

Phytoplankton biomass, measured as $\mathrm{Chl} a$, was 
higher in October with the highest values at site 3 (Figs. 2 and 3). In May, Chl $a$ with P-alone addition did not increase significantly $(\mathrm{P}<0.05)$ compared with the control, while $\mathrm{N}$ addition treatments $(+\mathrm{N}$ and $+\mathrm{NP})$ had significantly $(\mathrm{P}<0.05)$ positive effects on $\mathrm{Chl} a$, providing an evidence of $\mathrm{N}$ limitation. It should be called, more exactly serial $N$ limitation - a response to $\mathrm{N}$-alone addition $(+\mathrm{N})$ and a larger response with the simultaneous addition of $\mathrm{P}$ (+NP) (Kolzau et al., 2014). Without $\mathrm{N}$ enrichment in May, Chl $a$ increased with time but this trend was not significant $(\mathrm{P}>0.05)$ at site 1 and site 2 . However, strong $\mathrm{P}$ limitation was observed in October, where $\mathrm{P}$ addition $(+\mathrm{P}$ and $+\mathrm{NP}$ treatments) significantly stimulated an increase in phytoplankton biomass $(\mathrm{P}<0.05)$ while $+\mathrm{N}$ treatment did not $(\mathrm{P}>0.05)$. In this case, it should be called single $P$ limitation - a response to only $\mathrm{P}$-alone addition and the response to the combined treatment $(+\mathrm{NP})$ is not different.
Without $\mathrm{P}$ addition in October, Chl $a$ initially increased for $\sim 3$ days and decreased afterwards due to P deficiency.

In both seasons, bacterial biomass gradually increased across all treatments at all three sites. Although not statistically significant, $\mathrm{N}$ enrichment appeared to stimulate an increase in biomass in May, with a larger response to both nutrients (+NP). However, nutrients enrichment did not contribute significantly to bacterial biomass in October except for the +NP treatment at site 2 . These results suggested that, unlike phytoplankton, bacteria do not experience severe nutrient stress, especially for P uptake.

\section{DRP drawdown and DOP production}

Initial DRP concentrations in the Ezhen area ranged between 5.20-5.30 $\mu \mathrm{g} \mathrm{\textrm {L } ^ { - 1 }}$ and varied significantly $(\mathrm{P}<0.05)$ across three sites (Fig. 4). Negative rates of DRP,

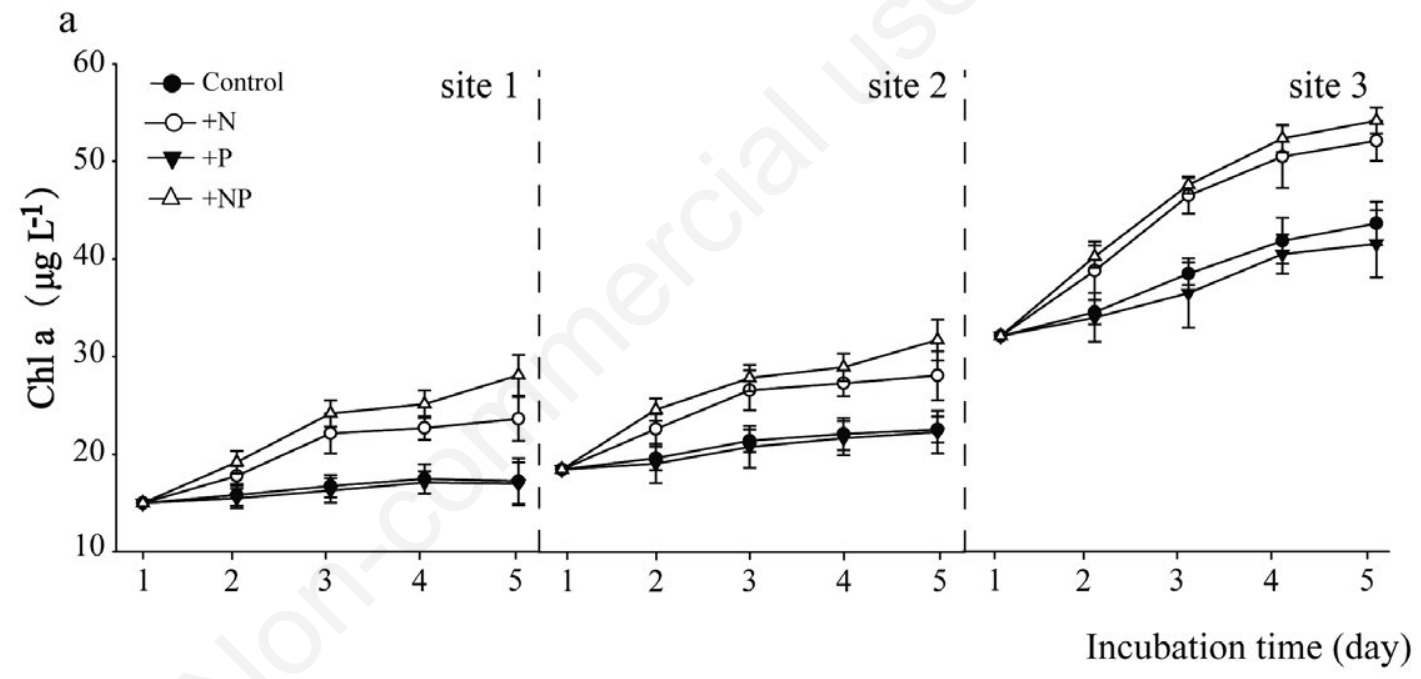

b

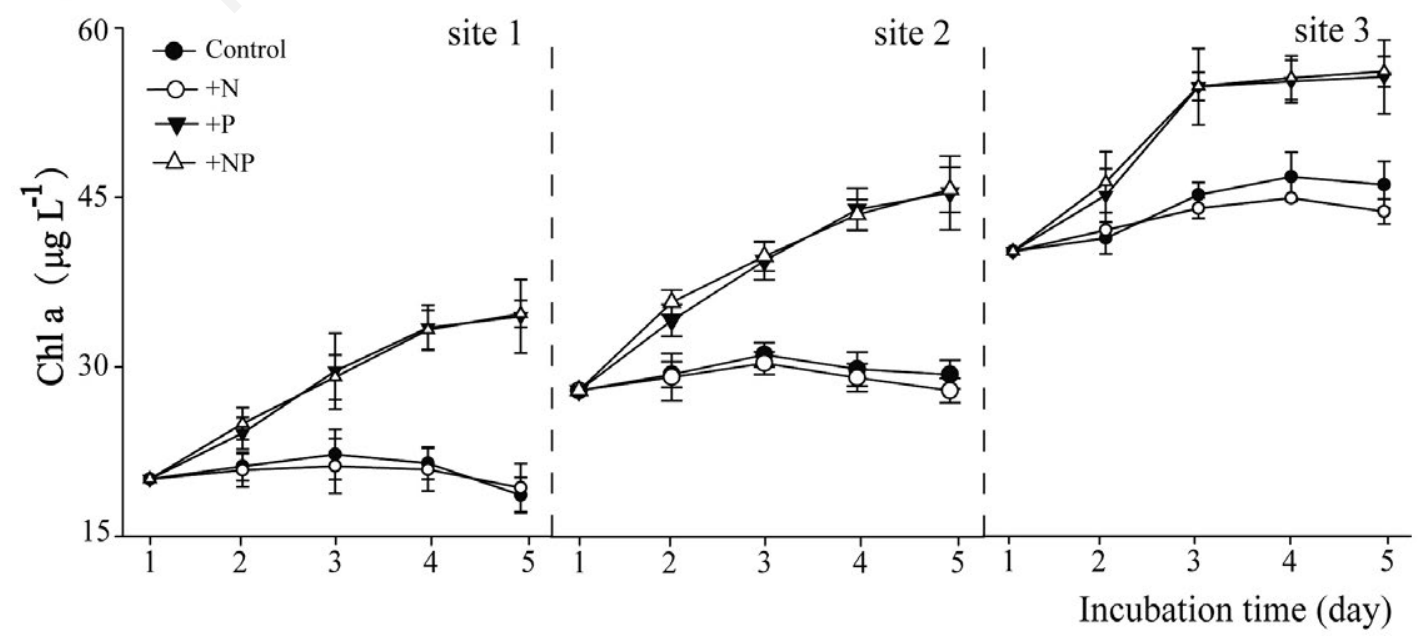

Fig. 2. Phytoplankton biomass during the incubation bioassays in May (a) and October (b). 
which indicated DRP drawdown, were observed from the very beginning of incubation in all treatments. Compared with control treatment, rates of DRP drawdown increased with $\mathrm{N}$ addition. For example, at site 3 in May, DRP concentration in $+\mathrm{N}$ treatment decreased after 3 days to $1 \mu \mathrm{g}$ $\mathrm{L}^{-1}$ and was not measurable by day 5 , a significantly lower value $(\mathrm{P}<0.05)$ than that in the control $\left(2 \mu \mathrm{g} \mathrm{L}^{-1}\right)$. For $\mathrm{P}$ addition treatments $(+\mathrm{P}$ and $+\mathrm{NP})$, DRP consumption reached its maximum, but only consistently induced a significant increase in Chl $a$ in October.

DOP concentration during the incubation reflects a balance between generation (exudation, excretion, de novo production, etc.) and utilization (enzymatic hydrolysis). DOP was the major fraction of TDP and accounted for an average percentage of $81.25 \%$ for the two seasonal bioassays. Initial DOP concentrations ranged between 28.92-118.00 $\mu \mathrm{g} \mathrm{L}^{-1}$ and the highest values were observed at site 3 (Fig. 5). DOP utilization occurred in all treatments across seasons, regardless of the system being Plimited or not. For control and $+\mathrm{N}$ treatments, DOP declined over time. For $+\mathrm{N}$ treatment, DOP was significantly $(\mathrm{P}<0.05)$ lower than that in the control in October, but increased slightly above the control in May. By comparison, DOP concentrations were significantly $(\mathrm{P}<0.05)$
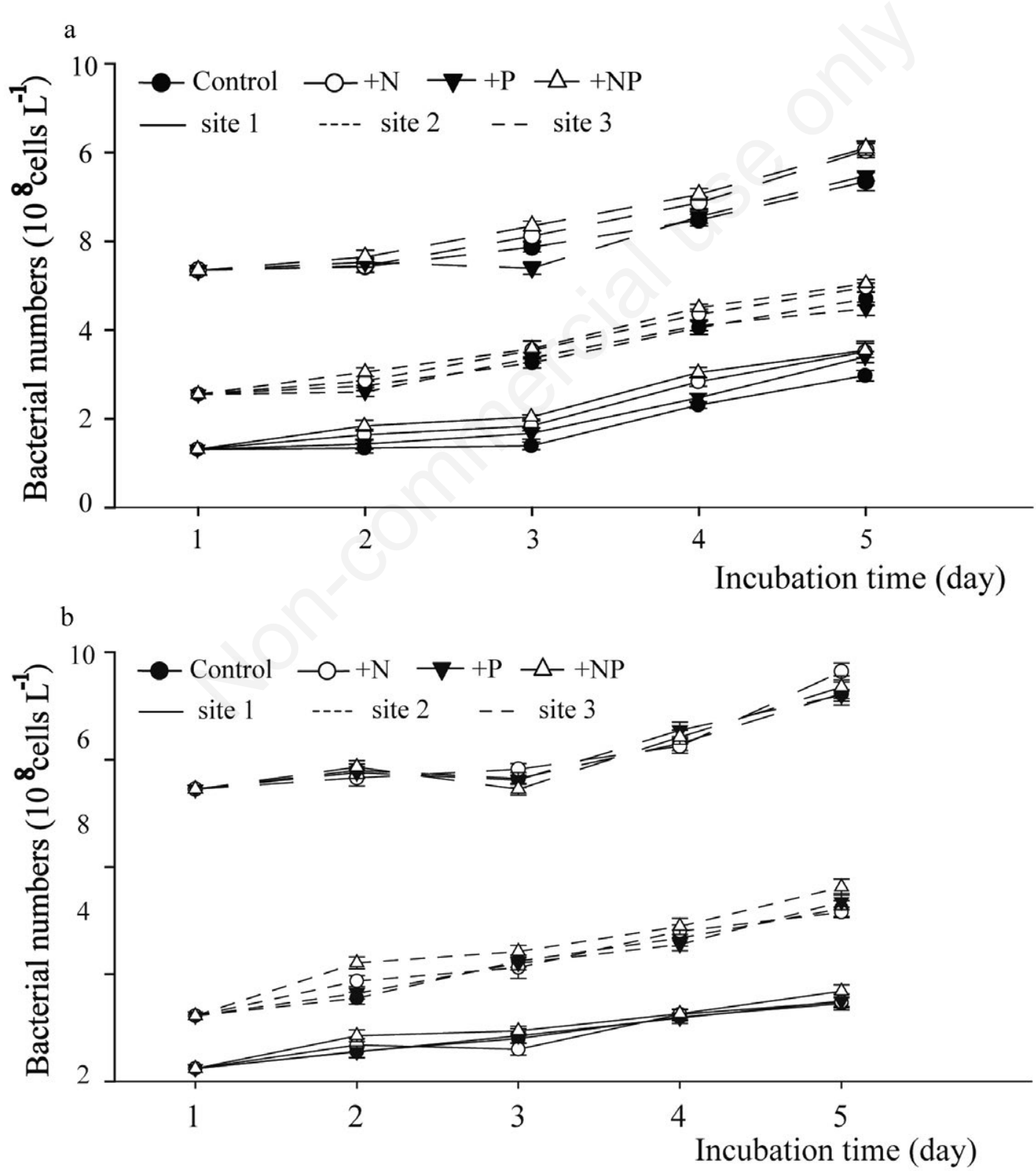

Fig. 3. Bacterial biomass during the incubation bioassays in May (a) and October (b). 
elevated with $\mathrm{P}$ addition ( $+\mathrm{P}$ and $+\mathrm{NP}$ treatments) in both May and October although there was no difference between $+\mathrm{P}$ and $+\mathrm{NP}$ treatments $(\mathrm{P}<0.05)$.

\section{Variation of APA fractions}

During the two seasonal bioassays, bulk APA increased gradually in the control and $+\mathrm{N}$ treatments (Fig. 6). Compared with the control, APA was significantly $(\mathrm{P}<0.05)$ higher in $+\mathrm{N}$ treatment and was strongly repressed with $\mathrm{P}$ addition ( $+\mathrm{P}$ and $+\mathrm{NP}$ treatments). APA was significantly higher in $+\mathrm{NP}$ treatment than that in $+\mathrm{P}$ treatment. A hysteresis phenomenon was observed, meaning that large fluctuations of bulk APA began from day-2 on, while it showed slighter changes at the beginning of the incubation. Significantly $(\mathrm{P}<0.05)$ lower DRP and higher bulk APA were observed at site 3 , suggesting larger $\mathrm{P}$ demand and DOP utilization compared with the other two sites.
A similar pattern of variation was found in phyt-APA, as it was the major contributor of bulk APA at most times (52.73\% in average) (Fig. 7). In contrast, the contributions of bact-APA and free APA were complex with no apparent regularity. Bact-APA and free APA represented on average 21.09 and $26.18 \%$, respectively. In general, both phytAPA and bact-APA increased with $\mathrm{N}$ addition and declined with $\mathrm{P}$ addition. However, at site 1 and site 2 in May, bact-APA did not decline as expected, but instead increased in $+\mathrm{P}$ treatment, while declining to low values with $\mathrm{N}$ addition.

\section{DISCUSSION}

\section{Nutrient limitation for phytoplankton}

Seasonal increases of integrated $\mathrm{Chl} a$ and primary production in this study corroborate previous evidence in eutrophic shallow lakes that phytoplankton recovery oc-
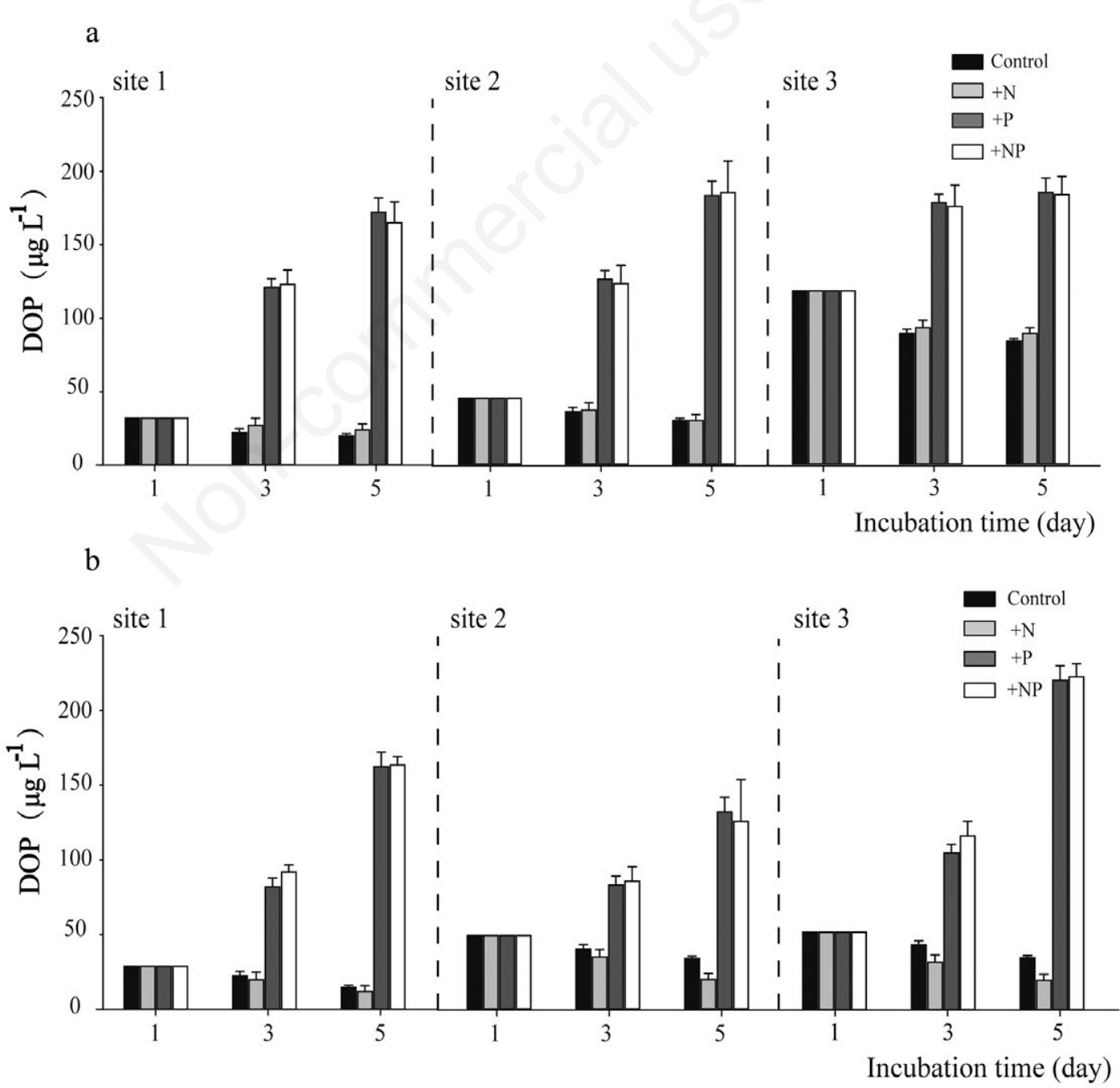

Fig. 4. Dissolved reactive phosphorus (DRP) drawdown during the incubation bioassays in May (a) and October (b). 
curs in spring and blooms occur between summer and autumn (Kong and Gao, 2005). DRP, a key regulatory factor in the growth and dominance of freshwater microorganisms (Xie et al., 2003), was at low levels in the Ezhen throughout the study. However, low concentrations may not necessarily indicate limitation and it may represent efficient recycling and utilization.

Traditionally, determination of $\mathrm{N}$ and $\mathrm{P}$ limitation in an ecosystem is based on the relative water column N:P ratios (Redfield ratio) (Nicholson et al., 2006) because of their impact on phytoplankton biomass (reviewed by Rhee, 1978; Xie et al., 2003; Aslan and Kapdan, 2006). However, this analytical determination does not account for potentially bioavailable nutrient forms, such as DOP. Generally, $\mathrm{P}$ is believed to function as the primary limiting nutrient (Elser et al., 1990), with $\mathrm{N}$ having little effect on phytoplankton biomass (Schindler et al., 2008), but this is not consistent with the observations in this study. In May, Chl $a$ increased significantly with $\mathrm{N}$ addition $(+\mathrm{N})$, with a substantially larger response to both nutrients $(+\mathrm{NP})$ (serial N limitation), but P-alone $(+\mathrm{P})$ had no significant influence. This did not meet the expectation that $\mathrm{P}$ was the primary limiting nutrient during spring when the algae began to recover and develop. The absence of $\mathrm{P}$ limitation in May in the Ezhen area despite low DRP concentrations may also partially be explained by luxury uptake, where some phytoplankton species can take up $\mathrm{P}$ faster than it is deployed and utilize these P stores to sustain growth for a long time (Reynolds, 2006).

In October significant increases of Chl $a$ with P-alone addition was observed (single $\mathrm{P}$ limitation), indicating that although DRP had not yet been depleted but that it was

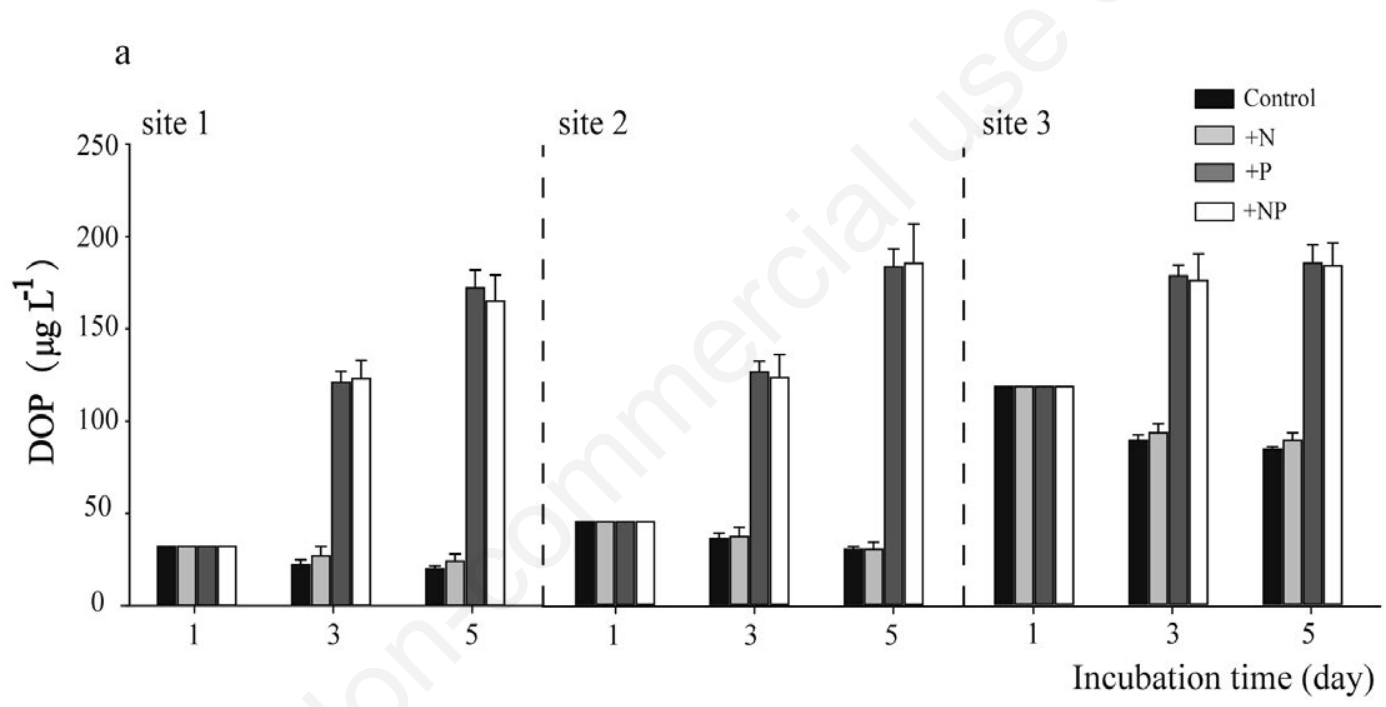

b

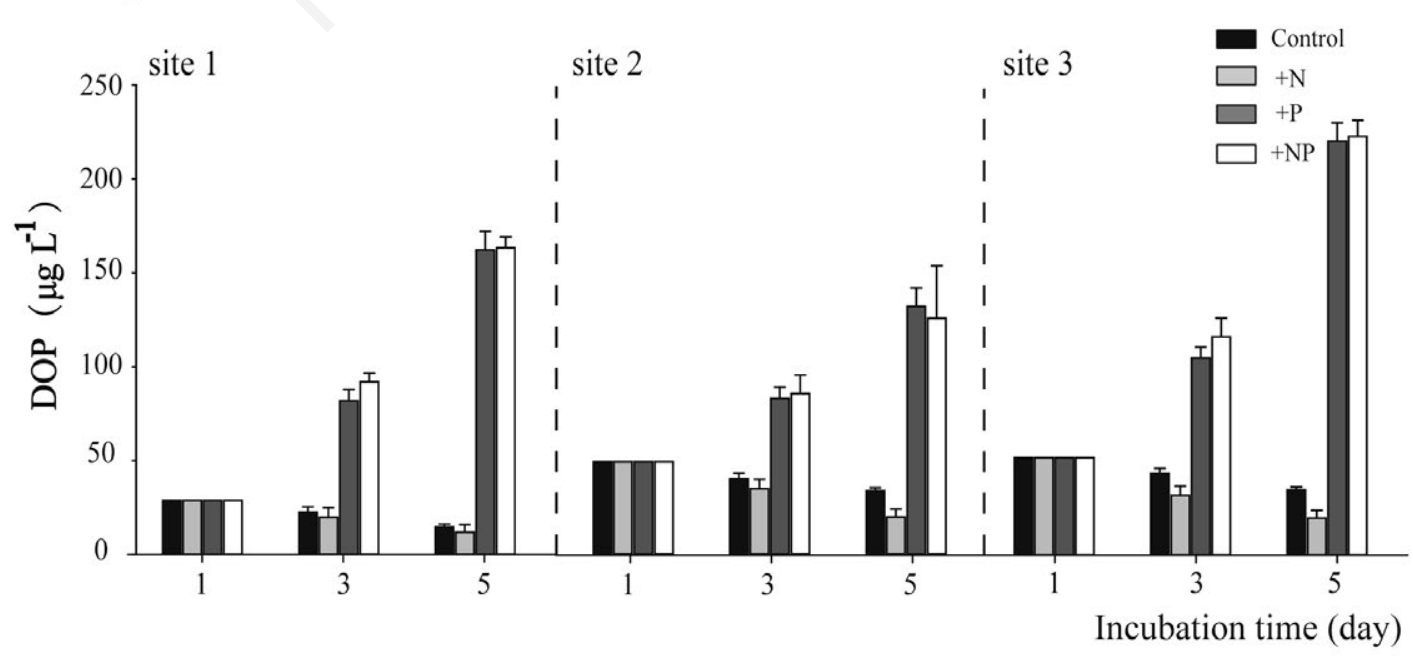

Fig. 5. Dissolved organic phosphorus (DOP) production during the incubation bioassays in May (a) and October (b). 
already insufficient to support phytoplankton growth. It might be that denitrification is a potentially crucial $\mathrm{N}$ loss mechanism in spring (Seitzinger, 1988) and drives systems toward $\mathrm{N}$ limitation. Besides, it is possible that the main phytoplankton populations in May belonged to a non-nitrogen-fixing algae genus and highly dependent on exogenous $\mathrm{N}$ sources. Other studies have found that seasonal shifts in nutrient limitation for phytoplankton may take place with changed allochthonous nutrient loads (Fisher et al. 1992). Thus, the variability in patterns of nutrient limitation in this study may reflect the pulsed nature of rainfall and riverine discharge events.

Results indicated that field verification of nutrient limitation of phytoplankton and its potential for control of algal blooms should be investigated with caution. Although $\mathrm{P}$ reduction may be important for controlling blooms in October, $\mathrm{N}$ load reduction is probably more critical during late spring in May. Consequently, an effective nutrient management strategy in the Ezhen area should include control of both $\mathrm{N}$ and $\mathrm{P}$, focusing on different nutrients in during different parts of the year.

\section{Regulation patterns of APA}

APase is commonly generated by various organisms, including bacteria and different phytoplankton taxa (Jansson, 1976; Cembella et al., 1984). Different APA fractions (phytoplankton, bacteria and free) have been considered as good indicators of algal and bacterial P stress at the total community level (Labry et al., 2005). The ability of phytoplankton to utilize APA to hydrolyze DOP is advantageous for persistence in low DRP environments, although this is not the case for bacteria (Hoppe, 2003). Following a similar variation pattern, phyt-APA com-
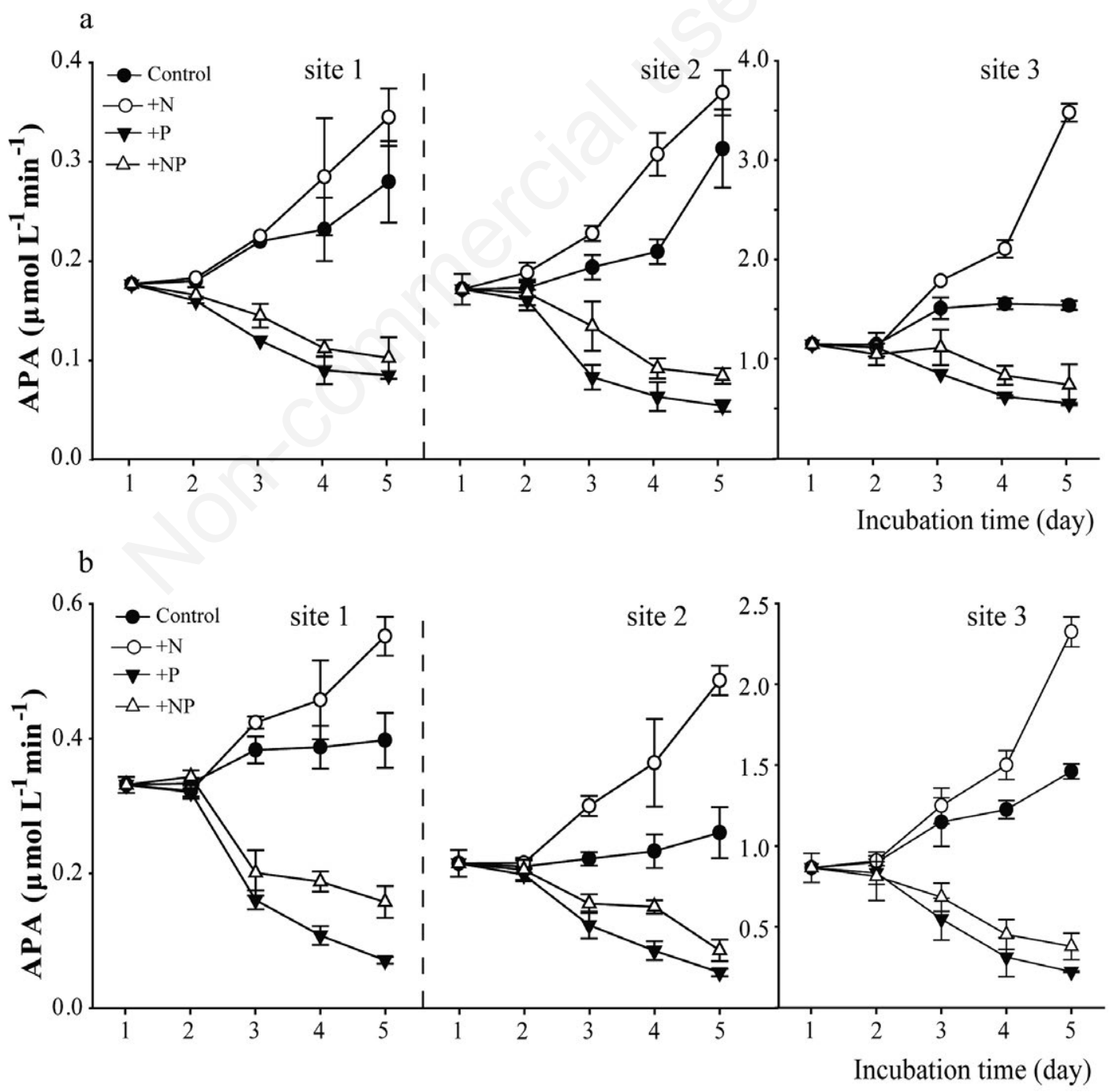

Fig. 6. Bulk alkaline phosphatase activity (APA) variations during the incubation in May (a) and October (b). 
prised the largest proportion of bulk APA at nearly all times, while the contribution of bact-APA was substantially lower. Therefore, DOP could be an important source of $\mathrm{P}$ for phytoplankton during periods of $\mathrm{P}$ depletion.

During $+\mathrm{N}$ treatments, $\mathrm{P}$ demand was promoted and microorganisms were stimulated in increase APA (bulk and specific APA). In contrast, the repletion of $\mathrm{P}$ fueled phytoplankton or bacteria and their production of APA could be repressed. It should be noted for bacteria that bact-APA has an additional function to provide organic carbon compounds, which mainly originates from algal exudates (Hoppe, 2003). Consequently, bact-APA increased significantly $(\mathrm{P}<0.05)$ when phytoplankton biomass was low in $+\mathrm{P}$ treatment at sites 1 and 2 in May, but decreased to low values when phytoplankton biomass increased in $\mathrm{N}$ addition treatments.

The expression of APA is typically triggered by low
DRP levels and thus can be used to assess short term changes in bioavailable P (Ammerman, 1991; Cembella et al., 1984; Chróst, 1991). In the Ezhen area, initial bulk APA was high in May but the limiting nutrient seemed to be N. This suggests that high APA does not necessarily indicate $\mathrm{P}$ limitation of phytoplankton biomass, but instead should be considered an indicator of physiological P stress (Dyhrman and Ruttenberg, 2006). This result provides evidence for the suggestion of Rose and Axler (1998) that bulk APA may not provide sufficient information to indicate $\mathrm{P}$ status when $\mathrm{N}$ or $\mathrm{N}+\mathrm{P}$ are limiting.

Although APA and DRP showed a strong inverse relationship at separate sites in this study, the correlation was discrepant for the whole dataset (Fig. 8a). Thus, these results only partially support previous evidence for robust inverse correlations between APA and DRP (Labry et al., 2005; Kwon et al., 2011). Varying environmental condi-

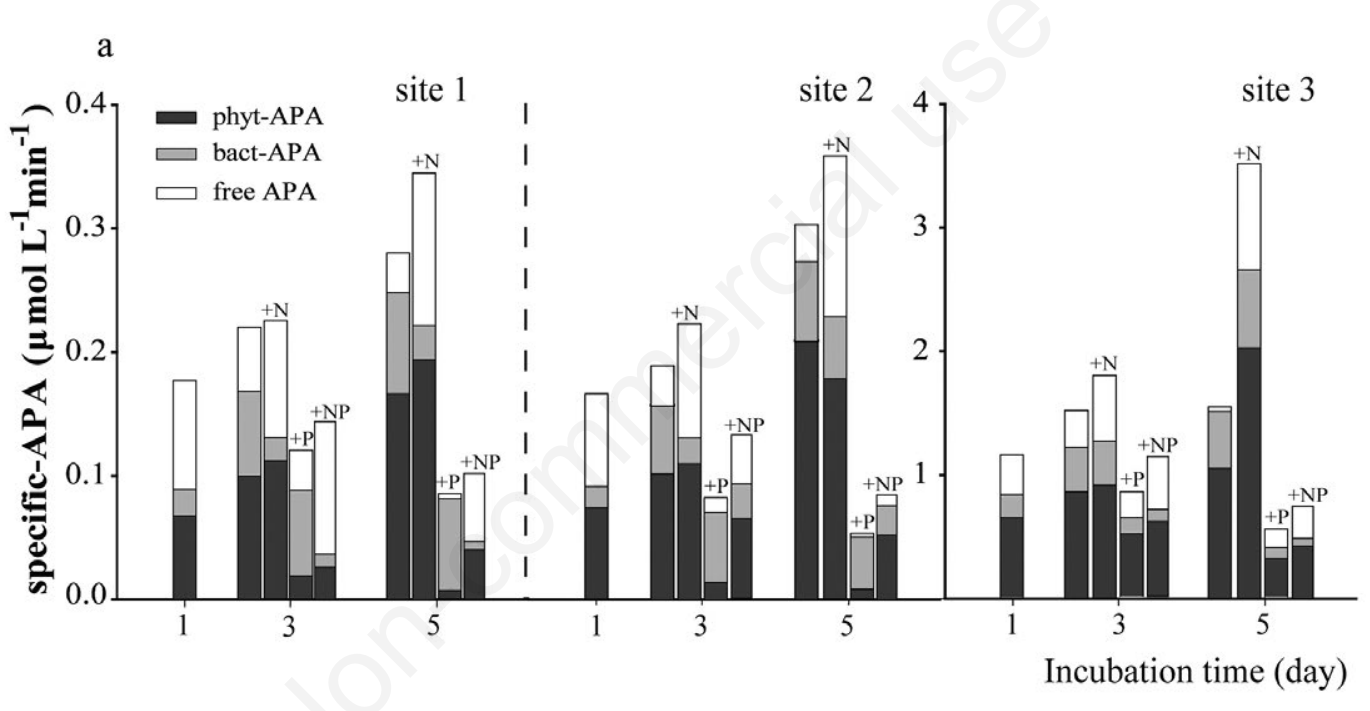

b

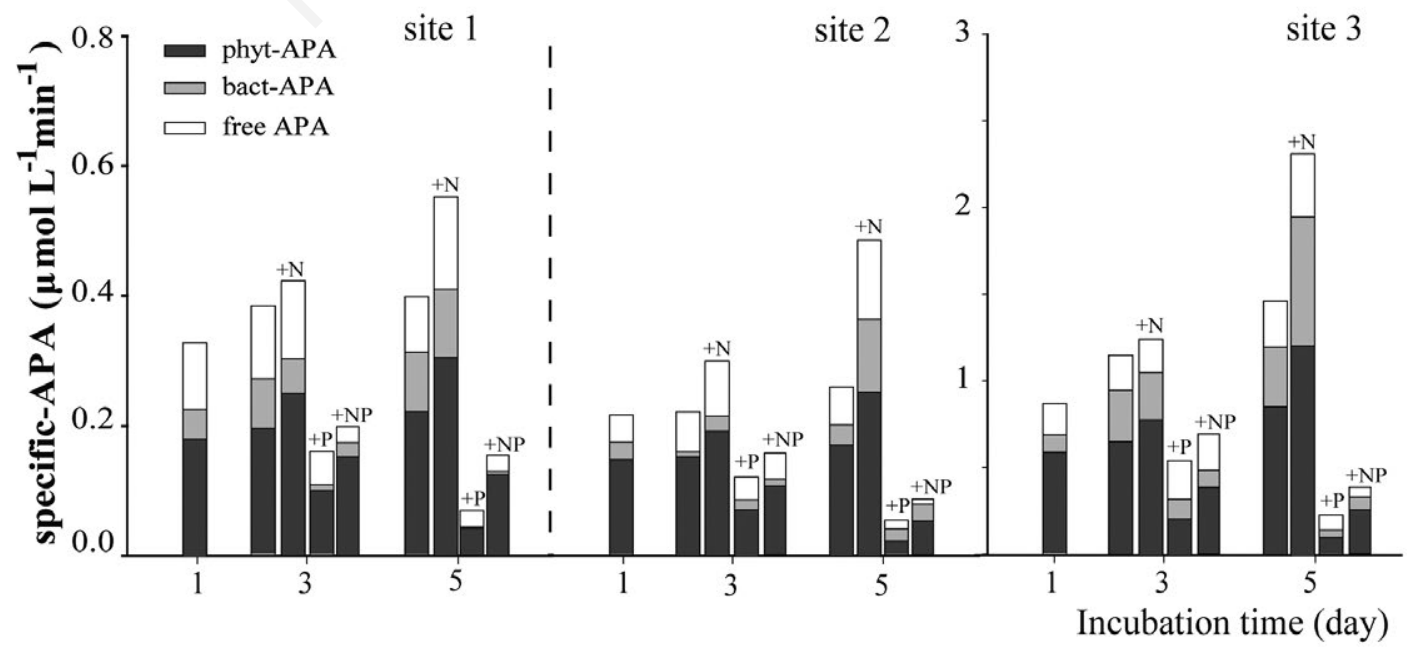

Fig. 7. Specific alkaline phosphatase activity (APA) variations during the incubation bioassays in May (a) and October (b). 
tions may be one cause for the differing results among sites (Jin et al., 2006). For example, water residence time has an important influence on P cycling, where rapid flushing time may decouple effects on APA and DRP (Ruttenberg and Dyhrman, 2005). In this study, regulation of APA was demonstrated by an inverse hyperbolic relationship between bulk APA, specific APA, and DRP, with a transition from high to low activity occurring between 20 and $50 \mu \mathrm{g}$ $\mathrm{L}^{-1}$ (Fig. 8). It was consistent with Cao et al. (2010) that, the so-called induction-repression mechanism held true with lower DRP and it can be swamped or reversed with relatively higher DRP status (Nausch, 1998; Sebastian et al., 2004). The APA-DRP relationship was not significant for bacteria (Fig. 8c) owing to the simultaneous production of organic carbon compounds by bact-APA (Hoppe, 2003).

\section{P cycling with nutrients enrichment}

In nutrient-limited environments, small size and large cell surfaces may enable bacteria to compete for nutrients (Duhamel et al. 2010). Although slight increases of bacterial biomass with $\mathrm{N}$ addition were observed in May, $\mathrm{P}$ addition did not significantly affect growth in either season. It is possible that bacteria experience less serious $\mathrm{P}$ stress with $\mathrm{P}$ depletion than phytoplankton, which increased and dominated $\mathrm{P}$ uptake with $\mathrm{P}$ addition, as seen by a rapid decline in phyt-APA. This pattern is consistent with the findings of $\mathrm{Xu}$ et al. (2008) that phytoplankton dominate uptake at high levels of DRP, while bacteria are superior at uptake under low concentrations of DRP. Therefore, phytoplankton likely took up most imported $\mathrm{P}$ and bacteria were less P-limited at most times. For example, Chl $a$ did not increase with the DRP utilization as expected in the control and $+\mathrm{N}$ treatments in October.

DOP is known to be produced during DRP assimilation within complex lake food webs. In our study, P uptake and DOP production were significantly different among treatments. With $\mathrm{N}$-alone addition, DRP drawdown and DOP utilization increased, but the balance between DOP generation and consumption differed during the two seasons. It was suggested that phytoplankton may have either synthesized or excreted more DOP than they utilized in May, increasing DOP slightly relative to the control. In October, however, higher negative DOP production was observed in $+\mathrm{N}$ treatment compared with the control. In contrast, with $\mathrm{P}$ addition $(+\mathrm{P}$ and $+\mathrm{NP}$ treatments), DOP increased dramatically relative to the control in both seasons, indicating DOP utilization was minimal and a conversion of DRP to DOP occurred. In May, DOP increased significantly in $+\mathrm{P}$ treatment despite the absence of phytoplankton bloom. Moreover, although Chl $a$ increased significantly in $+\mathrm{NP}$ treatment relative to $\mathrm{P}$-alone addition $(+\mathrm{P})$ in May, DOP production did not $(\mathrm{P}<0.05)$. It seemed that substantial new biomass is probably not required to generate DOP.
Our study provides insight into the responses of microbial biomass, APA fractions, and the variation patterns of $\mathrm{P}$ cycling under changing nutrient conditions, and thus may be useful to estimate the influences and predictions by the observed results. For example, during springtime, when utilization of $\mathrm{N}$ fertilizers for agricul-

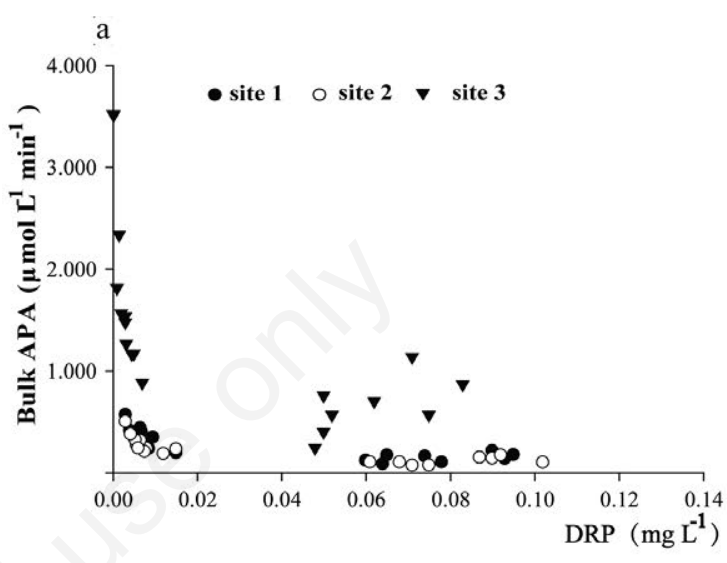

b
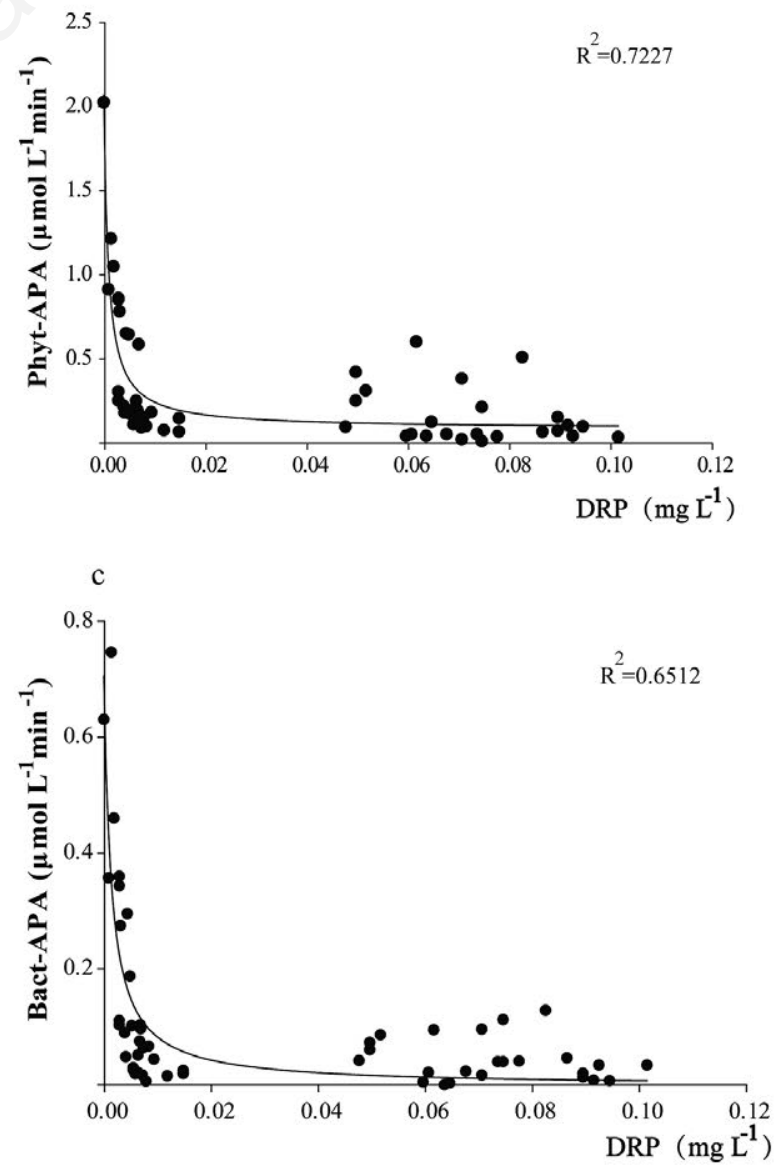

Fig. 8. Relationship among DRP and bulk alkaline phosphatase activity (APA) (a); phyt-APA (b); and bact-APA (c). 
ture is at a maximum (Gao et al., 2004), rivers tend to be enriched in nitrate and ammonium. With significant riverine input into Ezhen, our results indicate that phytoplankton biomass may be stimulated and result in higher DOP utilization. Conversely, in the autumn it may be more important to monitor the discharge of DRP-rich wastewater, which is likely to result in higher net DOP production and export.

\section{CONCLUSIONS}

Our main conclusions are:

i) Low levels of DRP in the Ezhen area do not necessarily indicate $\mathrm{P}$ limitation. In May, phytoplankton exhibited serial N-limitation with $P$ stress, such that biomass increased significantly with $\mathrm{N}$ addition. In October the limiting nutrient shifted to $\mathrm{P}$, and phytoplankton growth was significantly enhanced by $P$ addition.

ii) Phytoplankton was responsible for the majority of APA, yet high levels of bulk APA were also not necessarily indicative of $\mathrm{P}$ limitation. Bacteria experienced less serious P stress compared with phytoplankton. Microorganisms were stimulated to increase APA in $+\mathrm{N}$ treatment and APA could be significantly repressed with $\mathrm{P}$ addition, but this was not consistent with bact-APA.

iii) The correlation between bulk APA and DRP was good at separate sites and discrepant for the whole data set. APA regulation showed an inverse hyperbolic relationship between bulk APA, specific APA, and DRP, with a transition occurring from high to low activity.

iv) $\mathrm{N}$ addition significantly increased DRP drawdown and DOP utilization. Contrastingly, with $\mathrm{P}$ addition DOP utilization was minimal, and phytoplankton converted a large portion of DRP to DOP.

\section{ACKNOWLEDGMENTS}

We are grateful for the grants from the National Natural Science Funds for Distinguished Young Scholar (No. 51225901), Jiangsu Province Science Fund for Distinguished Young Scholar (No. BK2012037), Major Special S\&T Project on Water Pollution Control and Management under the Ministry of Environmental Protection, PR China (No. 2012ZX07101-008), Innovative Research Team in University of Ministry of Education of China (No. IRT13061), and the Jiangsu Qinglan Project.

\section{REFERENCES}

Ammerman JW, 1991. Role of ecto-phosphohydrolases in phosphorus regeneration in estuarine and coastal ecosystems, $p$. 165-186. In: R.J. Chróst (ed.), Microbial enzymes in aquatic environments. Springer.

Anderson DM, Glibert PM, Burkholder JM, 2002. Harmful algal blooms and eutrophication: nutrient sources, composition, and consequences. Estuaries 25:704-726.
APHA, 1995. Standard methods for the examination of water and wastewater, $19^{\text {th }}$ ed. American Water Works Association, Water Environment Federation.

Aslan S, Kapdan IK, 2006. Batch kinetics of nitrogen and phosphorus removal from synthetic wastewater by algae. Ecological Engineering 28:64-70.

Boyer JN, Dailey SK, Gibson PJ, Rogers MT, Mir-Gonzalez D, 2006. The role of dissolved organic matter bioavailability in promoting phytoplankton blooms in Florida Bay. Hydrobiologia 569:71-85.

Cao XY, Song CL, Zhou YY, 2010. Limitations of using extracellular alkaline phosphatase activies as a general indicator for describing P deficiency of phytoplankton in Chinese shallow lakes. J. Appl. Phycol. 22:33-41.

Carpenter SR, 2005. Eutrophication of aquatic ecosystems: bistability and soil phosphorus. P. Natl. Acad. Sci. USA 102: 10002-10005.

Cembella AD, Antia NJ, Harrison PJ, Rhee GY, 1984. The utilization of inorganic and organic phosphorous compounds as nutrients by eukaryotic microalgae: a multidisciplinary perspective: part 1. Crit. Rev. Microbiol. 11:13-81.

Chróst RJ, 1991. Environmental control of the synthesis and activity of aquatic microbial ectoenzymes, p. 29-59. In: R.J. Chróst (ed.), Microbial enzymes in aquatic environments. Springer.

Chróst RJ, Overbeck J, 1987. Kinetics of alkaline phosphatase activity and phosphorus availability for phytoplankton and bacterioplankton in Lake Pluhsee (North German Eutrophic Lake). Microb. Ecol. 13:229-248.

Correll DL, 1998. The role of phosphorus in the eutrophication of receiving waters: a review. J. Environ. Qual. 27:261-66.

Duhamel S, Dyhrman ST, Karl DM, 2010. Alkaline phosphatase activity and regulation in the North Pacific Subtropical Gyre. Limnol. Oceanogr. 55:1414-1425.

Dyhrman ST, Ruttenberg KC, 2006. Presence and regulation of alkaline phosphatase activity in eukaryotic phytoplankton from the coastal ocean: implication for dissolved organic phosphorus remineralization. Limnol. Oceanogr. 51:1381-1390.

Dyhrman ST, Webb EA, Anderson DM, Moffett JW, Waterbury JB, 2002. Cell-specific detection of phosphorus stress in Trichodesmium from the Western North Atlantic. Limnol. Oceanogr. 47:1832-1836.

Elser JJ, Marzolf ER, Goldman CR, 1990. Phosphorus and nitrogen limitation of phytoplankton growth in the freshwaters of north America: A review and critique of experimental enrichments. Can. J. Fish. Aquat. Sci. 47:1468-1477.

Fisher TR, Peele ER, Ammerman JW, Harding LW Jr, 1992. Nutrient limitation of phytoplankton in Chesapeake Bay. Mar. Ecol.-Prog. Ser. 82:51-63.

Galloway JN, Cowling EB, 2002. Reactive nitrogen and the world: 200 years of change. Ambio 16: 64-71.

Gao C, Zhu JG, Zhu JY, Gao X, Dou YJ, Hosen Y, 2004. Nitrogen export from an agriculture watershed in the Taihu Lake area. China Environ. Geochem. Health 26:199-207.

Gao G, Zhu GW, Qin BQ, Chen J, Wang K, 2006. Alkaline phosphatase activity and the phosphorus mineralization rate of Lake Taihu. Sci. China Ser. D Earth Sci. 49:176-185.

Geraldes AM, Boavida MJ, 2003. Do distinct water chemistry, reservoirage and disturbance make any difference on phosphatase activity? J. Limnology 62: 613-171. 
Golterman HL, Clymo RS, Ohnstad MAM, 1978. Method for physical and chemical analysis of fresh waters. IBP Manual No 8. Blackwell Scientific: 213 pp.

Hecky RE, Kilham P, 1988. Nutrient limitation of phytoplankton in freshwater and marine environment: a review of recent evidences of the effects of enrichment. Limnol. Oceanogr. 33:796-822.

Hoppe HG, 2003. Phosphatase activity in the sea. Hydrobiologia 493:187-200.

Hu WP, Zhai SJ, Zhu ZC, Han HJ, 2008. Impacts of the Yangtze River Water Transfer on the restoration of Lake Taihu. Ecol. Engin. 34:30-49.

Hu LM, Hu WP, Zhai SH, Wu HY, 2010. Effects on water quality following water transfer in Lake Taihu, China. Ecol. Engin. 36:471-481.

Ivančić I, Fuks D, Radić T, Lyons DM, Šilović T, Kraus R, Precali R, 2010. Phytoplankton and bacterial alkaline phosphatase activity in the northern Adriatic Sea. Marine Environ. Res. 69:85-94.

Jansson M, 1976. Phosphatases in lakewater. Characteristics of enzymes from phytoplankton and zooplankton by gel filtration. Science 194:320-321.

Jin XC, Wang SR, Zhao HC, Bu QY, Chu JZ, Cui Z, Zhou XN, Wu FC, 2006. Effect of lake sediments of different trophic states on alkaline phosphatase activity. Lakes Reserv. Res. Manage. 11:169-176.

Jin $\mathrm{XC}, \mathrm{Hu} \mathrm{XZ}, 2003$. A comprehensive plan for treating the major polluted regions of Lake Taihu, China. Lakes Reserv. Res. Manage. 8:217-230.

Kolzau S, Wiedner C, Rücker J, Köhler J, Köhler A, Dolman AM, 2014. Seasonal patterns of nitrogen and phosphorus limitation in four German lakes and the predictability of limitation status from ambient nutrient concentrations. PloS One 9:e96065.

Kong FX, Gao G, 2005. [Hypothesis on cyanobacteria bloomforming mechanism in large shallow eutrophic lakes].[Article in Chinese]. Acta Ecologica Sinica 25:589-595.

Kwon HK, Oh SJ, Yang HS, 2011. Ecological significance of alkaline phosphatase activity and phosphatase-hydrolyzed phosphorus in the northern part of Gamak Bay, Korea. Mar. Poll. Bull. 62:2476-2482.

Labry C, Herbland A, Delmas D, 2002. The role of phosphorus on planktonic production of the Gironde plume waters in the Bay of Biscay. J. Plankton Res. 24:97-117.

Labry C, Delmas D, Herbland A, 2005. Phytoplankton and bacterial alkaline phosphatase activities in relation to phosphate and DOP availability within the Gironde plume waters (Bay of Biscay). J. Exper. Mar. Biol. Ecol. 318:213-225.

Lai GY, Yu G, Gui F, 2006. Preliminary study on assessment of nutrient transport in the Taihu Basin basedon SWAT modeling. Sci. China Ser. D Earth Sci. 49:135-145.

Liu H, Zhou Y, Xiao W, Lei J, Cao X, Song C, 2012. Shifting nutrient-mediated interactions between algae and bacteria in a microcosm: evidence from alkaline phosphatase assay. Microbiol. Res. 167:292-298.

Murphy J, Riley P, 1962. A modified single solution method for the determination of phosphate in natural waters. Anal. Chim. Acta. 27:31-36.

Nausch M, 1998. Alkaline phosphatase activities and the relationship to inorganic phosphate in the Pomeranian Bight
(Southern Baltic Sea). Aquat. Microb. Ecol. 16:87-94.

Nicholson D, Dyhrman S, Chavez F, Paytan A, 2006. Alkaline phosphatase activity in the phytoplankton communities of Monterey Bay and San Francisco Bay. Limnol. Oceanogr. 51:874-883.

Novotna J, 2010. Cell specific extracellular phosphatase activity of dinoflagellate populations in acidified mountain lakes. J. Phycol. 46:635-644.

Paerl HW, Bowles D, 1987. Dilution bioassays: their application to assessments of nutrient limitation in hypereutrophic waters. Hydrobiologia 146:265-273.

Paerl HW, 2008. Nutrient and other environmental controls of harmful cyanobacterial blooms along the freshwater-marine continuum. Adv. Experim. Med. Biol. 619:216-241.

Paerl HW, Xu H, McCarthy MJ, Zhu GW, Qin BQ, Li YP, Gardner WS, 2011. Controlling harmful cyanobacterial blooms in a hyper-eutrophic lake (Lake Taihu, China): the need for a dual nutrient $(\mathrm{N} \& \mathrm{P})$ management strategy. Water Res. 45:1973-1983.

Porter KG, Feig YS, 1980. The use of DAPI for identifying and counting aquatic microflora. Limnol. Oceanogr. 25:943-948.

Rabalais NN, 2002. Nitrogen in aquatic ecosystems. Ambio 16:102-112.

Ren LX, Wang PF, Li LN, 2013. Purifying effects of nitrogen in Wangyu River water through natural wetlands. Adv. Mater. Res. 664:87-93.

Rengefors K, Ruttenberg KC, Haupert CL, Taylor C, Howes BL, Anderson DM, 2003. Experimental investigation of taxonspecific response of alkaline phosphatase activity in natural freshwater phytoplankton. Limnol. Oceanogr. 48:1167-1175.

Reynolds CS, 1997. Vegetation processes in the Pelagic: a model for ecosystem theory. Ecology Institute, Germany: $371 \mathrm{pp}$.

Reynolds CS, 2006. Ecology of phytoplankton. Cambridge University Press: $552 \mathrm{pp}$.

Rhee GY, 1978. Effects of N: P atomic ratios and nitrate limitation on algal growth, cell composition, and nitrate uptake. Limnol. Oceanogr. 23:10-25.

Rose C, Axler RP, 1997. Uses of alkaline phosphatase activity in evaluating phytoplankton community phosphorus deficiency. Hydrobiologia 361:145-156.

Ruttenberg KC, Dyhrman ST, 2005. Temporal and spatial variability of dissolved organic and inorganic phosphorus, and metrics of phosphorus bioavailability in an upwelling-dominated coastal system. J. Geophys. Res.-Oceans 110:C10S13.

Ruttenberg KC, Dyhrman ST, 2012. Dissolved organic phosphorus production during simulated phytoplankton blooms in a coastal upwelling system. Front. Microbiol. 3:274.

Sañudo-Wilhemy SA, Kustka A, Gobler CJ, Hutchins DA, Capone DG, Raven JA, DiGiacomo PM, 2001. Phosphorus limitation of nitrogen fixation by Trichodesmium in the central Atlantic Ocean. Nature 411:66-69.

Schindler DW, Hecky RE, Findlay DL, Stainton MP, Parker BR, Paterson MJ, Kasian SEM, 2008. Eutrophication of lakes cannot be controlled by reducing nitrogen input: results of a 37-year whole-ecosystem experiment. P. Natl. Acad. Sci. USA 105:1254-11258.

Seitzinger SP, 1988. Denitrification in freshwater and coastal marine ecosystems: ecological and geochemical significance. Limnol. Oceanogr. 33:702-724.

Sebastian M, Aristegui J, Montero MF, Niell FX, 2004. Kinetics 
of alkaline phosphatase activity, and effect of phosphate enrichment: a case study in the NW African upwelling region. Mar. Ecol.- Prog. Ser. 270:1-13.

Smith VH, Tilman GD, Nekola JC, 1999. Eutrophication: impacts of excess nutrient inputs on freshwater, marine, and terrestrial ecosystems. Environ. Poll. 100:179-196.

Wetzel RG, 2001. Limnology. Lake and river ecosystems. 3. Academic Press: 1006 pp.

Xie LG, Xie P, Li SX, Tang HG, Liu H, 2003. The low TN:TP ratio: a cause or a result of Microcystis blooms? Water Res. 37:2973-2080.

Xu H, Paerl HW, Qin B, Zhu G, Gao G, 2010. Nitrogen and phosphorus inputs control phytoplankton growth in eutrophic Lake Taihu, China. Limnol. Oceanogr. 55:420-432.

Xu J, Yin K, He L, Yuan X, Ho AY, Harrison PJ, 2008. Phosphorus limitation in the northern South China Sea during late summer: influence of the Pearl River. Deep-Sea Res. Pt. I 55:1330-1342.

Yang LY, 2004. Research on nutrient dynamics in the process of growth and metabolism of the dominated cyanobacteria in Lake Taihu, p. 209-217. In: B.Q. Qin, W.P. Hu and W.M. Chen WM (eds.), Evolvement process and mechanism of water environment in Lake Taihu. Science Press. 